\title{
Chloride uptake by tropical forage grasses in two soils of Puerto Rico',2
}

\author{
David Sotomayor-Ramírez ${ }^{3}$ and Jaime Moyá 4
}

J. Agric. Univ. P.R. 84(3-4):133-142 (2000)

\begin{abstract}
An experiment was conducted on two dairy farms in Puerto Rico (Gurabo and Cidra) from September 1998 to July 1999 with the objective of quantifying chloride $(\mathrm{Cl})$ concentrations and uptake in grazed forage. All plots were fertilized with the equivalent amount of 330,110 , and $220 \mathrm{~kg} / \mathrm{ha} / \mathrm{yr}$ $\left(\mathrm{N}, \mathrm{P}_{2} \mathrm{O}_{5}, \mathrm{~K}_{2} \mathrm{O}\right)$ and the treatments consisted of four $\mathrm{Cl}$ levels $(0,82,164$, and $328 \mathrm{~kg} / \mathrm{ha} / \mathrm{yr}$ ) split in four applications. Forage was harvested every 28 days during the seven-month experiment. Plant $\mathrm{Cl}^{-}$concentrations were determined by means of a potentiometric titration in the laboratory. Yields (fresh and dry weight) were not significantly affected by $\mathrm{Cl}$ levels, which suggests that background soil concentrations were sufficiently high so as not to limit plant growth. Mean monthly $\mathrm{Cl}$ concentrations in forage tissue were significantly affected by $\mathrm{Cl}$ levels, increasing from 0.79 to $0.82 \%$ in Cidra and from 0.68 to $0.96 \%$ in Gurabo. Cumulative $\mathrm{Cl}$ uptake by forage in the sevenmonth study period for the highest $\mathrm{Cl}^{-}$treatment was 124 and $161 \mathrm{~kg} / \mathrm{ha}$ in Cidra and Gurabo, respectively. Our data suggest that excess $\mathrm{Cl}$ in milk does not necessarily originate from $\mathrm{Cl}$-containing fertilizer. Estimated $\mathrm{Cl}$ consumption by dairy cows consuming tropical forages and concentrate is higher than that suggested by the U.S. National Research Council.
\end{abstract}

Key words: tropical forages, chloride uptake, chloride in milk

\section{RESUMEN}

Utilización de cloruro por forrajeras tropicales en dos suelos de Puerto Rico

Se realizó un experimento en dos suelos de dos vaquerías (Gurabo y Cidra) desde septiembre de 1998 a julio de 1999 con el objetivo de cuantificar las concentraciones y utilización de cloruro $(\mathrm{Cl})$ en forraje utilizado para pastoreo. Todas las parcelas recibieron el equivalente de 330,110 , and 220 $\mathrm{kg} / \mathrm{ha} / \mathrm{año}\left(\mathrm{N}, \mathrm{P}_{2} \mathrm{O}_{5}, \mathrm{~K}_{2} \mathrm{O}\right.$, respectivamente) y los tratamientos consistieron en la aplicación de cuatro niveles de $\mathrm{Cl}(0,82,164$, y $328 \mathrm{~kg} / \mathrm{ha} / \mathrm{año})$ divididos en cuatro aplicaciones. El forraje se cortó cada 28 días, durante siete meses. El contenido de $\mathrm{Cl}^{-}$en tejido seco se determinó por medio de una titulación potenciométrica en el laboratorio. Los rendimientos (materia seca y materia fresca) no se afectaron significativamente con las aplicaciones de

${ }^{1}$ Manuscript submitted to Editorial Board 26 May 2000.

${ }^{2}$ We appreciate the financial assistance of Ochoa Fertilizer Corp., Empresas Fonalledas, and UPR-RUM-AES. Lorimar Figueroa diligently helped in $\mathrm{Cl}$ analysis.

"Associate Professor, Agronomy and Soils Dept., College of Agricultural Sciences, UPR-RUM Mayagüez Campus.

${ }^{1}$ Assistant Researcher, Animal Industry Dept, College of Agricultural Sciences, UPRAES, Gurabo. 
$\mathrm{Cl}$, to cual sugiere que las concentraciones del suelo eran to suficientemente altas como para no ser limitantes al crecimiento vegetativo. Las concentraciones promedio mensuales de $\mathrm{Cl}^{-}$en el tejido de forraje se afectaron significativamente con los niveles de $\mathrm{Cl}$ aplicados, aumentado desde 0.79 a $0.82 \%$ en Cidra y desde 0.68 a $0.96 \%$ en Gurabo. Las cantidades totales de $\mathrm{Cl}$ extraídas por el forraje en un periodo de siete meses para el tratamiento con el nivel máximo fueron de 124 y $161 \mathrm{~kg} / \mathrm{ha}$ en Cidra y Gurabo, respectivamente. Los resultados obtenidos sugieren que fertilizantes que contienen muriato no necesariamente causan el exceso de $\mathrm{Cl}$ en leche detectado en algunos hatos lecheros. Estimados de consumo realizados demuestran que el consumo diario de $\mathrm{Cl}$ por el ganado vacuno lechero local es mayor que los valores nutritivos recomendados por el "National Research Council" de Ios E.U.

\section{INTRODUCTION}

Several dairy farms in Puerto Rico have been affected by chloride $\left(\mathrm{Cl}^{-}\right)$levels in milk exceeding established standards. This has had an adverse economic impact, as large quantities of milk have been ordered decommissioned by the ORIL (Oficina de Reglamentación de la Industria Lechera). High $\mathrm{Cl}^{-}$levels in milk have been associated with mastitis, colostrum, and with milk produced during the latter stages of lactation (Braun, 1946; Rook and Wheelock, 1967). A possible link between high $\mathrm{Cl}^{*}$ levels in milk and grazed forage high in $\mathrm{Cl}^{-}$content has been suggested. Some farmers have resorted to reducing fertilizer application rates (in search of a short term remedy) presumably because the cost of using an alternate source of potash other than potassium chloride is higher.

The speciation of $\mathrm{Cl}^{-}$in soil is mainly as a free ion in solution (Sparks, 1995), and because of its high mobility it can be rapidly cycled through soil. It behaves similarly to $\mathrm{NO}_{3}$ in soil and even competes with this ion for carrier sites in the plant root, although it is not subject to the same microbial transformations that otherwise would immobilize or remove it from soil (Marschner, 1995). Chloride can accumulate where the internal drainage of soils is restricted and in shallow groundwater where $\mathrm{Cl}^{-}$can be moved by capillarity into the root zone and deposited at or near the soil surface. It is classified as an essential element for plant growth with critical levels in wheat (Triticum aestivum) of approximately $0.4 \%$ in plant tissue and of $32 \mathrm{mg} / \mathrm{kg}$ in soil (Engel et al., 1998). Studies in which crop response to chloride has been examined have shown that plant tissue concentration can exceed $1.0 \%$ when soil plus fertilizer Cl- exceeds $100 \mathrm{~kg} / \mathrm{ha}$ (Fixen, 1993).

No formal study has been conducted to examine the effect of $\mathrm{Cl}^{-}$in fertilizer containing muriate of potash on grazed forage $\mathrm{Cl}$ concentration. As it has been shown in some crops that the plant will utilize $\mathrm{Cl}^{-}$ in relation to the amount in solution it seems logical that high $\mathrm{Cl}^{-}$con- 
centrations could exist in forage tissue. The potassium source in most commercial fertilizers used on forage in Puerto Rico is muriate of potash, containing approximately $47 \% \mathrm{Cl}$. Enhanced $\mathrm{Cl}^{-}$concentrations in plant tissue may be found in areas where recommended rates of fertilization are used and where $\mathrm{Cl}^{-}$cycling is restricted by soil and prevailing climatic conditions. The objective of this experiment was to evaluate the effects of application of fertilizer containing muriate of potash on plant forage $\mathrm{Cl}^{-}$concentrations.

\section{MATERIALS AND METHODS}

The experiment was conducted on the University of Puerto Rico Gurabo Agricultural Experiment Station dairy farm (Gurabo) and on a private dairy farm in Cidra Puerto Rico (Cidra). The soil at Cidra is a Humatas clay (clayey, mixed, isohyperthermic Typic Haplohumults), and at Gurabo a Mabí clay (fine, montmorillonitic, isohyperthermic Vertic Eutropepts). Soil $(0-15 \mathrm{~cm}) \mathrm{pH}$, organic matter (\%), extractable P (ppm, Bray1-P) were 6.3, 3.1, and 12.0 in Gurabo, and 4.9, 1.9, and 17 in Cidra, respectively. Upon initiating the experiment, the vegetation was a mixed stand of stargrass (Cynodon nlemfuensis), guineagrass (Panicum maximum), malojillo (Brachiaria purpurascens) and grama colorada (Axonopus compressus).

At both sites, the experiment was arranged in a randomized complete block design with four replications. The blocks were randomly placed in a 1-ha field in Gurabo and a 1.2-ha field in Cidra. Plots $(3 \times 3$ $\mathrm{m}$ ) within each block were established and surrounded by barbed wire to exclude grazing animals. All plots received maximum recommended fertilizer rates of 330,110 , and $220 \mathrm{~kg} / \mathrm{ha} / \mathrm{yr}\left(\mathrm{N}, \mathrm{P}_{2} \mathrm{O}_{5}, \mathrm{~K}_{2} \mathrm{O}\right.$, respectively), divided into four equal applications. The first application was on 14 October 1998, followed by applications after harvest in December 1998, February 1999, and May 1999. The treatments consisted of applications of $0,82,164$, and $328 \mathrm{~kg} \mathrm{Cl} / \mathrm{ha}$, respectively, amounts which corresponded to $0 \times, 0.5 \times, 1 \times$, and $2 \times\left(x=\right.$ times) the $\mathrm{Cl}^{-}$level applied (164 kg Cl/ha) in $2,200 \mathrm{~kg} / \mathrm{ha}$ of a complete fertilizer sold commercially. The Cl- levels were added by varying the $\mathrm{K}_{2} \mathrm{SO}_{4}$ and $\mathrm{KCl}$ ratios in the fertilizer mixture of the first three treatments and adding $\mathrm{NaCl}$ in the $2 \times$ treatment. This approach assured that all plots received the same $\mathrm{K}_{2} \mathrm{O}$ level and that $\mathrm{Cl}^{-}$was the only independent variable.

The experiment was established 14 October 1998, at which time an initial cutting evened out plant growth, and the plots were fertilized. Forage sampling was initiated in December 1998. Plant material was harvested by cutting ( 5 to $10 \mathrm{~cm}$ from soil surface) in a 1- $\mathrm{m}^{2}$ quadrant at approximately 28-day intervals for a total of seven harvests during 
1998-1999. Fresh weights were determined in the field. Dry forage yields were calculated from moisture determination on subsamples that were placed in a forced air oven at $65^{\circ} \mathrm{C}$ for $48 \mathrm{~h}$. Dried plant material was ground to pass a $1.0-\mathrm{mm}$ sieve and analyzed for $\mathrm{Cl}^{-}$by potentiometric titration using a specific ion electrode (LaCroix et al., 1970).

Data were subjected to analysis of variance using GLM procedure (SAS Institute, 1996). Data were analyzed as a split-plot in time with $\mathrm{Cl}^{-}$treatments as whole plots and dates as split-plots. Treatment means were separated by Fisher's Least Significant Difference test. A separate analysis was run for each site because a site $\times$ date $\times$ treatment interaction was observed with regards to plant $\mathrm{Cl}^{-}$concentration and uptake. Precipitation data were obtained from the meteorological stations at Gurabo and at Cayey (about $8 \mathrm{~km}$ from the study site).

\section{RESULTS AND DISCUSSION}

Forage yields (fresh and dry weight) at neither location were significantly affected by $\mathrm{Cl}^{-}$applications (Table 1). Dry forage yields were primarily influenced by sampling date (Figure 1). Only dry forage yield data is shown in Figure 1 since the pattern was the same for both fresh and dry yields. The general trend at both sites was for forage yields to pattern antecedent rainfall (Figure 2) and to increase in the next harvest following fertilization. Plots were fertilized 14 October 1998 and following each harvest: 10 December 1998, 5 February 1999, and 5 May 1999. Increases in day length also influenced the amount of forage yields. When averaged across $\mathrm{Cl}$ treatments for the seven-month study period, fresh and dry forage yields per harvest averaged 10,511 and 2,090 $\mathrm{kg} / \mathrm{ha}$ at Cidra and 12,055 and $2,314 \mathrm{~kg} / \mathrm{ha}$ at Gurabo, respectively.

The fresh and dry forage yields are comparable to those of previously published results for similar mixed grass stands in Puerto Rico when extrapolated to an annual basis (Vicente-Chandler et al., 1983; Welch et al., 1997). In Gurabo, fresh forage yields changed both in terms of direction and in amount as a result of $\mathrm{Cl}^{-}$application level and date of harvest (significant $\mathrm{T} \times \mathrm{D}$ interaction) (Table 1 ). It remains to be seen whether this finding has any practical meaning because the significance level for this interaction is only marginal $(P=0.053)$, dry forage yields were not significant, and $\mathrm{Cl}^{-}$application was not expected to affect yields. Although we did not measure soil Cl- levels, it appears that these were above minimum critical levels as reported by Engel et al. (1998); therefore, plant responses to $\mathrm{Cl}^{-}$applications were not observed.

A significant date $\times$ treatment interaction was observed for forage $\mathrm{Cl}^{-}$concentration but not for $\mathrm{Cl}^{-}$uptake in Cidra (Table 1, Figure 3), where mean monthly uptake values ranged from 11.3 to $23.7 \mathrm{~kg} / \mathrm{ha}$. 
TABLE 1.-The effect of $\mathrm{Cl}$ level (treatment), harvest date, and their interaction on yields of fresh and dry forage, plant $\mathrm{Cl}$ concentration and $\mathrm{Cl}$ uplake from December 1998 to June 1999 on two dairy farms (Cidra and Gurabo) of the east-central zone of Puerto Rico.

\begin{tabular}{|c|c|c|c|c|}
\hline \multirow[b]{2}{*}{ Factors } & Fresh forage yield & Dry forage yield & \multirow{2}{*}{$\begin{array}{c}\text { Plant } \mathrm{Cl}^{-} \\
\%\end{array}$} & \multirow{2}{*}{$\begin{array}{l}\mathrm{Cl} \cdot \text { uptake } \\
\mathrm{kg} \mathrm{Cl} / \mathrm{ha}\end{array}$} \\
\hline & \multicolumn{2}{|c|}{$\mathrm{kg} / \mathrm{ha} / \mathrm{harvest}$} & & \\
\hline \multicolumn{5}{|c|}{ Treatment $(\mathrm{T})^{1}$} \\
\hline \multicolumn{5}{|l|}{ Cidra } \\
\hline 0 & 10,580 & 2,083 & $0.709 \mathrm{~b}^{2}$ & 14.71 \\
\hline 82 & 10,462 & 2,090 & $0.722 \mathrm{~b}$ & 15.13 \\
\hline 164 & 10,539 & 2,104 & $0.788 \mathrm{ab}$ & 16.92 \\
\hline 328 & 10,462 & 2,086 & $0.824 \mathrm{a}$ & 17.75 \\
\hline$P \leq 3$ & NS & NS & 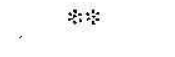 & NS \\
\hline \multicolumn{5}{|l|}{ Gurabo } \\
\hline 0 & 11,007 & 2,105 & $0.704 \mathrm{~b}$ & $14.99 \mathrm{c}$ \\
\hline 82 & 12,661 & 2,439 & $0.773 \mathrm{~b}$ & $18.99 \mathrm{~b}$ \\
\hline 164 & 11,977 & 2,307 & $0.907 \mathrm{a}$ & $21.13 \mathrm{ab}$ \\
\hline 328 & 12,575 & 2,408 & $0.927 a$ & $22.51 \mathrm{a}$ \\
\hline$P \leq$ & NS & NS & 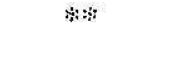 & $\Leftrightarrow$ \\
\hline \multicolumn{5}{|c|}{ Date (D) $P \leq$} \\
\hline Cidra & s* & $* a$ & wat & was \\
\hline Gurabo & Fit; & 称: & 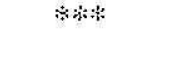 & 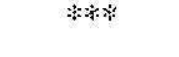 \\
\hline \multicolumn{5}{|l|}{$\mathrm{T} \times \mathrm{D} P \leq$} \\
\hline Cidra & NS & NS & $\%$ & NS \\
\hline Gurabo & $\%$ & NS & NS & $3:$ \\
\hline
\end{tabular}

'Fertilizer Cl' (kg/ha/yr).

${ }^{2}$ Means within columns followed by different letters are significantly different as determined by using Fisher's Least Significant Difference Test.

$3: *, * ;:$ indicates significance at probability levels of $0.05,0.01$, and 0.001 , respectively. NS denotes non-significance at a probability level of 0.05 .

The trend opposite to the one found in Cidra was observed in Gurabo, where the date $\times$ treatment interaction was significant only for $\mathrm{Cl}$ uptake. Here changes in plant $\mathrm{Cl}^{-}$concentration over sampling dates were not affected by differences in $\mathrm{Cl}^{-}$treatments and varied from 0.51 to $0.91 \%$ (Figure $3 \mathrm{~A}$ ). Critical values in plant vary from 0.1 to $0.7 \%$ for different crops (Fixen, 1993) with a value of $0.4 \%$ for wheat (Triticum aestivum L.) (Fixen, 1993; Engel et al., 1998). In Gurabo, increases in $\mathrm{Cl}$ uptake as affected by $\mathrm{Cl}$ application within harvest date (Figure 3B) appear to be indirectly influenced more by temporal changes in forage yields (as shown in Figure 1) than by plant $\mathrm{Cl}^{-}$concentration. Except for December and June sampling dates, the general trend was 


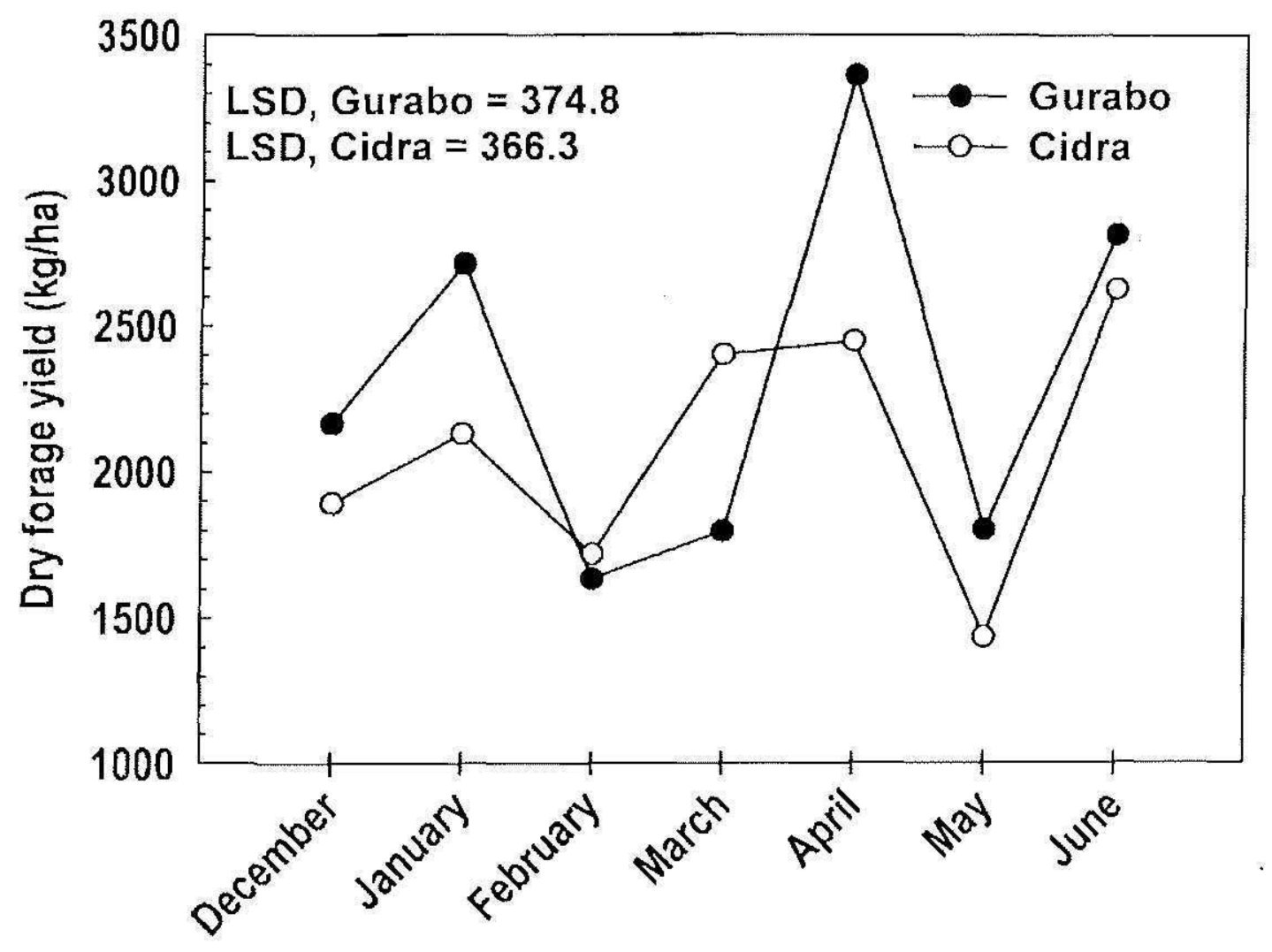

Months during 1998-1999

FIGURE 1. Dry forage yields fertilized with four $\mathrm{Cl}$ levels in Gurabo and Cidra, Puerto Rico. Only overall treatment means by date are presented because no significant treatment $\times$ date interaction occurred at a location.

for plant $\mathrm{Cl}^{-}$uptake to be highest with increasing $\mathrm{Cl}^{-}$application (Figure 3B). The opposite pattern was observed in Cidra, where $\mathrm{Cl}^{-}$ application within harvest did not influence yields nor uptake but did affect plant $\mathrm{Cl}$ concentrations.

In Cidra, no significant treatment effects on $\mathrm{Cl}$ - uptake were observed, although values increased with successive $\mathrm{Cl}$ application levels (Table 1). No significant differences in plant $\mathrm{Cl}^{-}$concentration were observed when $\mathrm{Cl}^{-}$was not applied as compared to the normal application rate. Doubling the $\mathrm{Cl}^{-}$application rate from 164 to $328 \mathrm{~kg} / \mathrm{ha}$ did not significantly affect plant $\mathrm{Cl}^{-}$concentrations.

In Gurabo, Cl- application rates of $82 \mathrm{~kg} / \mathrm{ha}$ (half the $\mathrm{Cl}^{-}$supplied in the recommended amount of commercial fertilizer) had no effect on plant $\mathrm{Cl}^{-}$concentrations while rates of 164 and $328 \mathrm{~kg} \mathrm{Cl}-/ \mathrm{ha}$ significantly increased plant $\mathrm{Cl}^{-}$concentrations (Table 2). Doubling the $\mathrm{Cl}^{-}$ application rate from 164 to $328 \mathrm{~kg} / \mathrm{ha}$ did not significantly affect plant $\mathrm{Cl}^{-}$concentrations. Also, plant $\mathrm{Cl}^{-}$concentration and $\mathrm{Cl}^{-}$uptake were significantly lower when $\mathrm{Cl}^{-}$was not applied than with the $164 \mathrm{~kg} / \mathrm{ha}$ rate. 


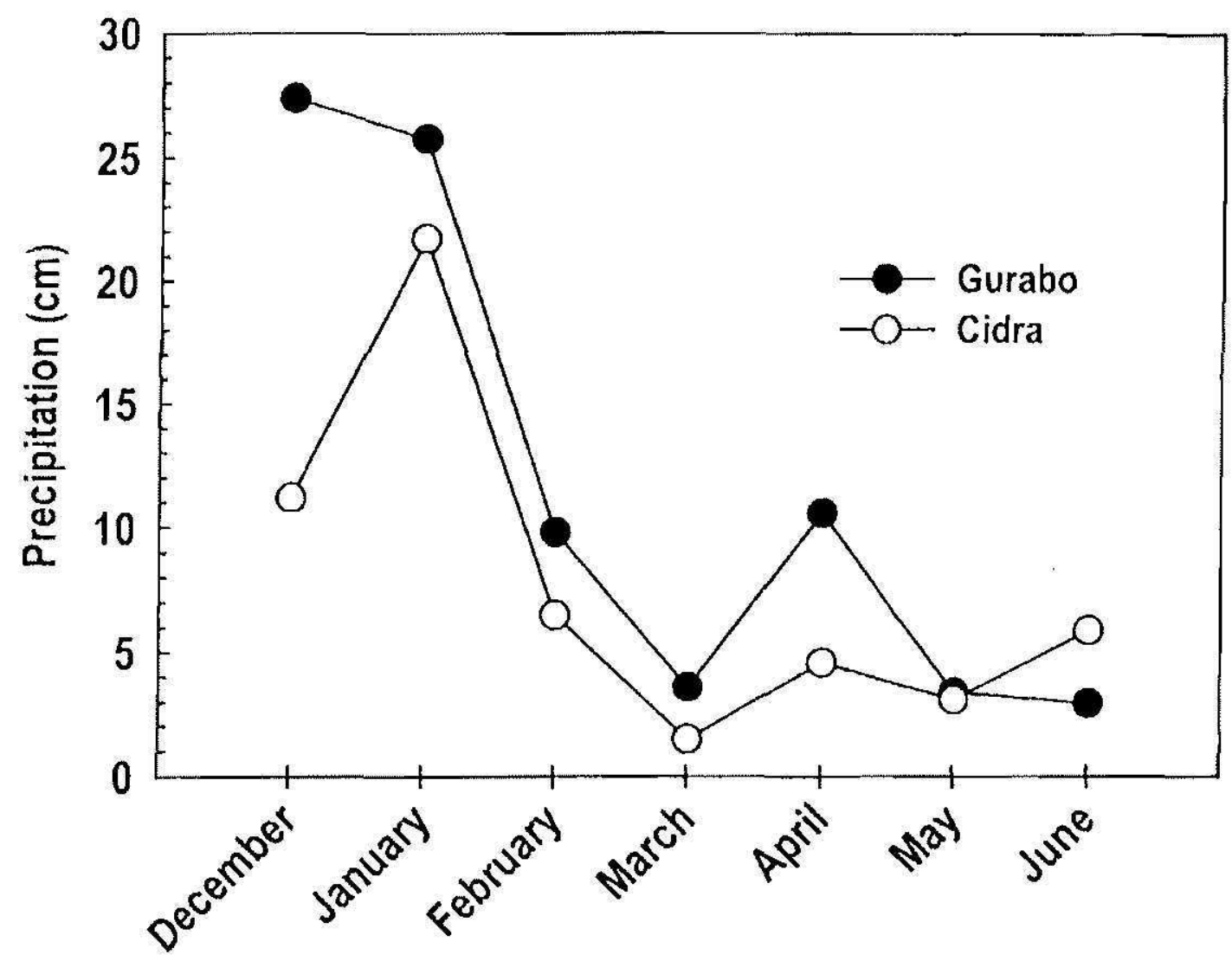

Months during 1998-1999

Figure 2. Monthly antecedent precipitation in Gurabo and Cidra during 1998-1999. Precipitation figures from Cidra were obtained from the nearest weather station at Cayey, Puerto Rico.

It was hypothesized that $\mathrm{Cl}^{-}$uptake would increase with higher $\mathrm{Cl}$ applications, and increases of $0.15 \mathrm{~kg} \mathrm{Cl}$ and $0.07 \mathrm{~kg} \mathrm{Cl}^{-}$for each $\mathrm{kg}$ of $\mathrm{Cl}^{-}$applied were observed in Gurabo and Cidra, respectively. After the February sampling date at both locations, the pattern of cumulative $\mathrm{Cl}^{-}$ uptake was consistently higher for the 164 and $328 \mathrm{~kg} \mathrm{Cl} / \mathrm{ha}$ as compared with the 0 and $82 \mathrm{~kg} \mathrm{Cl} / /$ ha application rates. Regression analysis between $\mathrm{Cl}^{-}$application and cumulative $\mathrm{Cl}^{-}$uptake extrapolated on an annual basis demonstrated that Cl- uptake ranged from 180 to $262 \mathrm{~kg} /$ ha in Gurabo and from 175 to $211 \mathrm{~kg} / \mathrm{ha}$ in Cidra for the 0 and maximum rates of $\mathrm{Cl}^{-}$application, respectively (data not shown). Chloride utilized by forages in unamended plots at both sites may be supplied by high background soil solution and exchangeable $\mathrm{Cl}$ - and atmospheric deposition of $\mathrm{Cl}^{-}$(Fixen, 1993).

Acid soils with clay mineralogy dominated by $1: 1$ clays and oxides, such as Humatas soil in Cidra, can have significant anion-exchange capacity, which may hold $\mathrm{Cl}^{-}$on exchange sites. Although such capacity 


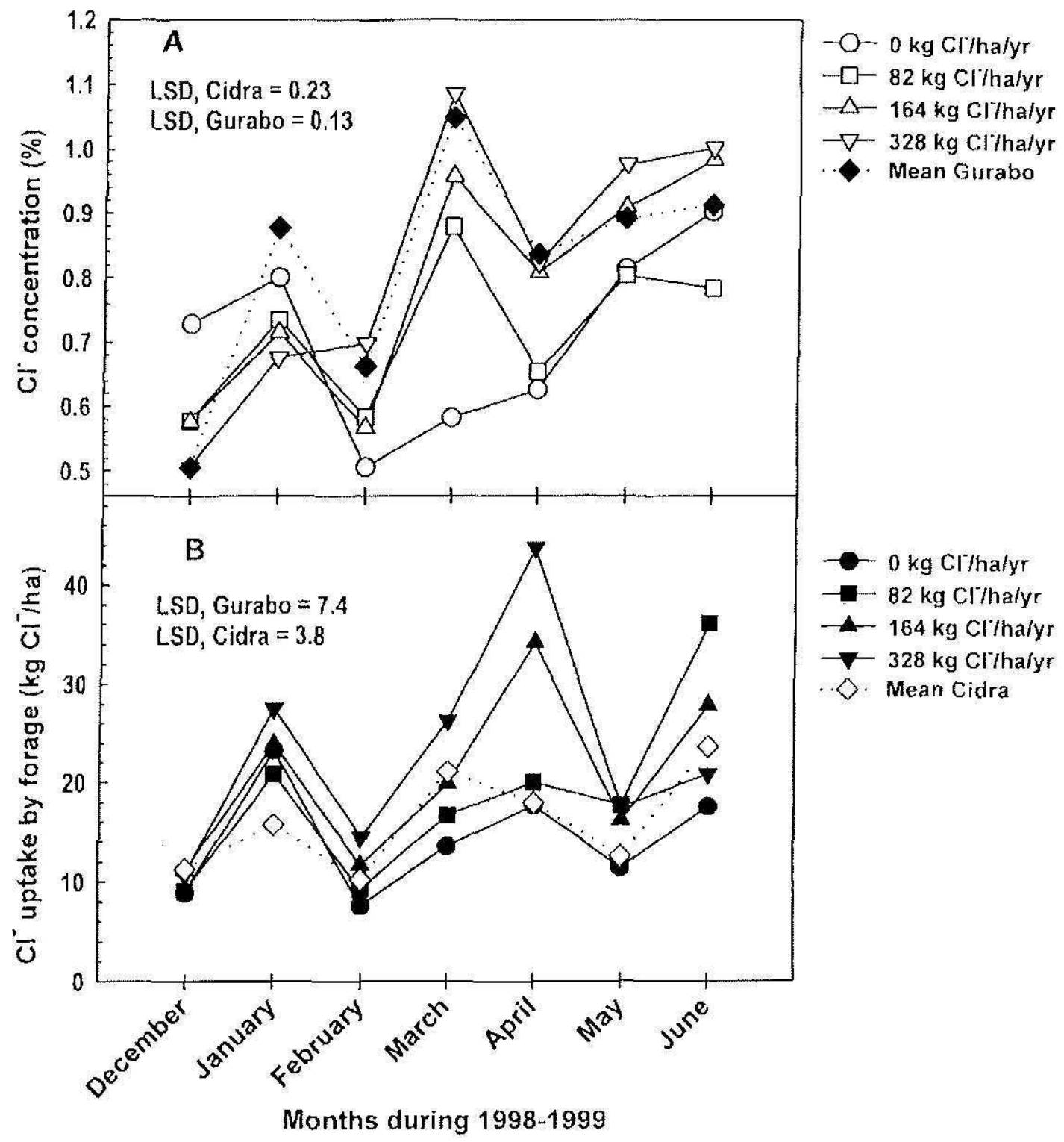

Figure 3. Concentration (A) and uptake (B) of $\mathrm{Cl}$ in forage fertilized with four $\mathrm{Cl}$ levels in 1998-1999 in Cidra (open symbols) and Gurabo (closed symbols), Puerto Rico. Only overall treatment means by date are presented when no significant treatment $X$ date interaction occurred at a location. In $(A)$ the LSD $(P=0.05)$ values for Cidra are for comparison of any means within dates, and for Gurabo for comparison between dates. In (B) the LSD ( $\mathrm{P}=0.05)$ values for Gurabo are for comparison of any means within dates and for Cidra for comparison between dates.

would not be expected in the Mabí soil at Gurabo, which has a higher $\mathrm{pH}$ and is dominated by $2: 1$ clays, these pastures had been previously fertilized and were under intense management prior to initiation of the experiment. Atmospheric deposition varies with geographic location, and precipitation near ocean shores can annually contribute as much as $100 \mathrm{~kg} \mathrm{Cl} / \mathrm{ha}$ (Fixen, 1993). The mobility of $\mathrm{Cl}$ - in soils suggests that 
TABI.I: 2.-Estimates of dietary $\mathrm{Cl}$ consumption by dairy cows of two clairy farms (Cidra and Curabo) of the cust-central zone of Puerto Rico compared to requirements suggested by the National Research Council (NRC).'

\begin{tabular}{|c|c|c|c|}
\hline Milk production & $\mathrm{NRC}^{2}$ & Gurabo & Cidra \\
\hline & $\cdots$ & $-\mathrm{kg} \mathrm{Cl} / \mathrm{d}-$. & $\ldots \ldots$ \\
\hline 10 & 0.03 & $0.05-0.06^{: 3}$ & 0.07 \\
\hline 20 & 0.04 & $0.07-0.08$ & $0.09-0.10$ \\
\hline 25 & 0.04 & $0.05-0.06$ & 0.09 \\
\hline
\end{tabular}

${ }^{1}$ Estimates are calculated using consumption levels obtained by NRC (1988) for dairy cows weighing $500 \mathrm{~kg}$ live weight, producing 10,20 , and $25 \mathrm{~kg} / \mathrm{d}$ of $4 \%$ fat corrected milk.

"Mean daily $\mathrm{Cl}$ consumption requirements suggested by NRC (1988).

${ }^{3}$ Minimum and maximum values, based on relative consumption of forage and concentrate (data obtained from AES-Gurabo) and $\mathrm{Cl}$ concentration in concentrate (this experiment). The $\mathrm{Cl}$ concentration in concentrate of Gurabo and Cidra for the month of May was 0.20 and $0.45 \%$, respectively.

leaching is the primary mode of CI- loss. Since actual leaching losses are dependent on several interacting factors, the persistence of $\mathrm{Cl}^{-}$in soil originating from the different mentioned sources is difficult to predict.

We measured $\mathrm{Cl}^{-}$concentrations in concentrate feed used with the herds at both sites, and estimated relative forage and concentrate consumption per lactating cow. Our estimated daily consumptions of $\mathrm{Cl}$ were higher than the $\mathrm{Cl}^{-}$requirements suggested by NRC (1988) (Table 3). Our $\mathrm{Cl}^{-}$concentration measurements included stems and leaves, whereas $\mathrm{Cl}$ - concentrations have been shown to be higher in leaves than in other plant parts (Fixen, 1993). Under grazing conditions where dairy cows are more selective, it is possible that these animals could be consuming larger amounts of $\mathrm{Cl}$ - than we estimate.

Coppock (1986) demonstrated that lactating cows were able to deal with excess dietary $\mathrm{Cl}^{-}$(up to 1.8 times the NRC requirements) without negative effects on the animal or quality of the milk. However, the amounts of $\mathrm{Cl}^{-}$fed to the animals by Coppock (1986) were lower than our estimated Cl- levels consumed by lactating dairy cows in Gurabo and Cidra. The fact that local lactating dairy cows are consuming relatively large quantities of $\mathrm{Cl}^{-}$year-round, and that relatively high $\mathrm{Cl}^{-}$ concentrations are found in forage tissue even when $\mathrm{Cl}^{-}$has not been applied, suggests that the occurrence of $\mathrm{Cl}^{-}$in milk exceeding established standards may be due to other factors rather than high $\mathrm{Cl}$ consumption by the cows. A physiological response to the thermally stressful environment by the lactating dairy cow could be a factor that needs to be addressed (Braun, 1946). In addition, $\mathrm{NRC} \mathrm{Cl}^{-}$requirements 
of intensively managed lactating dairy cows in tropical environments may need to be revised.

\section{LITERATURE CITED}

Braun, W., 1946. Average levels of various constituents, physical properties and formed elements of the cows on pasture. Am. J. Vet. Res. 7:450-4:54.

Coppock, C. E., 1986. Mineral utilization by the lactating cow-Chlorine. J. Dairy Sci. 69:595-603.

Engel, R. E, P. L. Bruckner and J. Eckhoff, 1998. Critical tissue concentration and chloride requirements for wheat. Soil Sci. Soc. Am. J. 62:401-405.

Fixen, P. E., 1993. Crop responses to chloride. Adv. Agron. 50:107-150.

Lacroix, R.L., D.R. Keeney and L.M. Walsh, 1970. Potentiometric titration of chloride in plant tissue extracts using the chloride ion electrode. Commun. Soil Sci. Plant Anal. 1:1-6.

Marschner, H., 1995. Mineral Nutrition of Higher Plants. Academic Press, Second ed. London.

National Research Council, 1988. Nutrient Requirements of Dairy Cattle. 6th revised ed. Natl. Aca. Sci. Washington, D.C.

Rook, J.A. and J.V. Wheelock, 1967. Reviews of the progress of dairy science. J. Dairy Sci. 34:273-286.

SAS Institute, 1996. SAS user's guide. Release 6.12. Windows ver. 4.0.1212. SAS Inst., Cary, NC.

Sparks, D. L., 1995. Environmental Soil Chemistry. Academic Press Inc, San Diego, CA.

Vicente-Chandler, J., R. Caro-Costas, F. Abruña and S. Silva, 1983. Producción y utilización intensiva de las forrajeras en Puerto Rico. UPR-RUM-CCA-EEA Boletin 271.

Welch, S. A., L. E. Sollenberger, T. M. Ruiz and C. R. Staples, 1997. Current management of tropical pastures to feed lactating dairy cattle in Puerto Rico. Proc. Carib. Food Crops. Soc. 33:151-163. 